\title{
Minha Casa Minha Vida: periferização, segregação e mobilidade intraurbana na área conurbada de Florianópolis
}

\author{
Minha Casa Minha Vida: peripheralization, segregation \\ and intra-urban mobility in the Florianópolis conurbation
}

Eduardo Leite Souza

Maria Inês Sugai

\begin{abstract}
Resumo
0 artigo investiga as repercussões na mobilidade urbana do processo de dispersão urbana e periferização impulsionado pelos empreendimentos do Programa Minha Casa Minha Vida na área conurbada de Florianópolis, que apresenta segregação socioespacial e disparidades de locomoção entre regiões centrais e periféricas. Constatou-se que empreendimentos subsidiados pelo programa habitacional se localizam-se, principalmente, em terrenos distantes, carentes de infraestruturas e transportes coletivos, acarretando em maiores custos e deseconomias, ao poder público e aos cidadãos. Evidencia que as políticas públicas de provisão habitacional dissociadas de estudos de localização intraurbana e mobilidade urbana repercutem no cotidiano através dos gastos com transporte, tempo dispendido nos deslocamentos, na periferização urbana e no exercíicio do direito à cidade, contribuindo para ampliar as desigualdades sociais e a segregação socioespacial.
\end{abstract}

Palavras-chave: periferização; mobilidade urbana; segregação socioespacial; Programa Minha Casa Minha Vida; Grande Florianópolis-SC.

\begin{abstract}
The article investigates the repercussions, on urban mobility, of the process of urban sprawl and peripheralization stimulated by the projects of the housing program Minha Casa Minha Vida in the Florianópolis conurbation (State of Santa Catarina, southern Brazil). The area presents socio-spatial segregation and locomotion disparities between central and peripheral districts. It was found that projects subsidized by the housing program are located mainly in distant sites, which lack infrastructure and public transportation, causing higher costs and diseconomies to the public and private realms. The article shows that housing policies disassociated from studies of intra-urban location and urban mobility have a daily impact on the lives of citizens through transportation expenses, time spent on commuting, and urban peripheralization. Furthermore, this affects the exercise of the right to the city, contributing to widen social inequalities and socio-spatial segregation.
\end{abstract}

Keywords: peripheralization; urban mobility; socio-spatial segregation; Minha Casa Minha Vida; greater Florianópolis - State of Santa Catarina. 


\section{Introdução}

0 debate sobre a mobilidade urbana das cidades brasileiras tem tido repercussão crescente, ainda que sempre tenha sido um problema para as camadas mais baixas da população. 0 assunto é geralmente abordado como uma questão mais técnica e de gestão, e não como o resultado de um processo social e territorial que abrange fatores como uso e ocupação do solo, densidades populacionais, distribuição socioespacial, localização de investimentos públicos e privados, além de conflitos de interesses e decisões políticas. A possibilidade aos deslocamentos intraurbanos transcende às meras soluções de obras viárias e modais de transportes e evidencia cotidianamente as desigualdades presentes nas sociedades e que se manifestam no espaço urbano. As dificuldades de acessibilidade, por sua vez, revelam o quanto as cidades brasileiras apresentam disparidades de oportunidades, que ampliam e reproduzem desigualdades sociais.

É imprescindível incluir no debate de mobilidade urbana a distribuição das camadas sociais no espaço urbano e a desigualdade de investimentos em determinadas porções das cidades, o que influencia diretamente o preço da terra e, consequentemente, o exercício do direito à cidade. Isso porque, mais do que as infraestruturas em si, o elemento que acrescenta qualidade e valorização a um terreno urbano é justamente sua localização, entendida como a proximidade de facilidades da vida urbana através da acessibilidade aos espaços de lazer, trabalho, serviços públicos -, produzidas por investimentos sucessivos em sistema viário, aberturas de ruas, estradas, transporte público.
Villaça (1986, p. 52) aponta que os conceitos de "perto e longe", "bem localizado e mal localizado" são construídos e desenvolvidos através dos interesses em explorar e se beneficiar com o valor da terra urbanizada. E o "perto e o longe" não podem ser reduzidos a simples distâncias físicas. São produzidos através dos sistemas de transportes, da disponibilidade de veículos para distintos estratos de renda (automóvel versus transporte público), através da distribuição espacial das camadas sociais, dos locais de emprego, das zonas comerciais, de serviços, entre outros.

Nesse contexto, utiliza-se o Programa Minha Casa Minha Vida (PMCMV) ${ }^{1}$ como estudo de caso, com foco na localização e inserção urbana dos conjuntos construídos na área conurbada de Florianópolis, no estado de Santa Catarina. As análises de diversos autores em âmbito nacional (Amore, Shimbo e Rufino, 2015; Amore, 2015; Cardoso, 2013; Ferreira, 2012; Pequeno e Rosa, 2015, entre outros) já demonstraram que os empreendimentos do programa têm sido geralmente construídos nos terrenos menos valorizados dos municípios, impulsionando processos de periferização, ocupação de franjas urbanas, criação de bairros monofuncionais afastados dos serviços públicos e dos empregos, demandando infraestruturas públicas diversas e acarretando custos urbanos acentuados. Entre esses custos, destaca-se o transporte coletivo que acaba ofertado num padrão baixo, induzindo à aquisição de veículos particulares para os deslocamentos diários. 0 objetivo deste artigo é apresentar o impacto que a inserção urbana dos empreendimentos do Programa Minha Casa Minha Vida exerce nos deslocamentos e na sua influência nas dinâmicas intraurbanas. 
0 trabalho utilizou o recorte espacial da área conurbada de Florianópolis, Santa Catarina, que engloba os municípios de Florianópolis, Biguaçu, São José e Palhoça. Nessa área geográfica, a mancha urbana é contínua e há fortes relações de interdependência entre os municípios, sobretudo de pendularidade. Como fonte principal de dados para o trabalho, utilizou-se o estudo do Plamus (Plano de Mobilidade Urbana Sustentável da Grande Florianópolis) (Logit Engenharia, Strategy e Machado Meyer, 2014), que se constituiu de um diagnóstico abrangente da mobilidade urbana de 13 municípios que compõem a Região Metropolitana de Florianópolis (RMF), ${ }^{2}$ desenvolvido durante 0 ano de 2014. Além disso, dados dos empreendimentos obtidos junto à Caixa Econômica Federal permitiram a confecção de diversas análises acerca dos empreendimentos do programa.

\section{Desigualdades sociais e segregação espacial na área conurbada de Florianópolis}

Florianópolis é frequentemente veiculada, na mídia, como um local de qualidade de vida superior ao contexto brasileiro, uma cidade segura e sem grandes problemas urbanos. Entretanto, sobretudo a região metropolitana enfrenta questões bastante problemáticas, como saneamento básico deficiente, transporte público oneroso e pouco eficiente, conflitos sociais, aumento da violência e crescimento das áreas de informalidade. Mas, atualmente, são os graves problemas de mobilidade urbana que causam sérios transtornos para a maior parte da população.

Só é possível compreender a atual dinâmica urbana de Florianópolis e seus recortes - como a de qualquer outra área conurbada - se for considerado o todo intraurbano, com as suas articulações e fragmentações, suas desigualdades e segregações, seus conflitos socioespaciais e contradições, a acessibilidade e 0 isolamento, a localização da riqueza e da pobreza, as disputas e as gestões locais, entre tantos aspectos da complexidade intraurbana. (Sugai, 2003, p. 2)

A ocupação urbana da RMF concentra-se na chamada área conurbada, abrangendo os municípios de Florianópolis, São José, PaIhoça e Biguaçu, nos quais se destacam fortes relações de dependência socioeconômica e de deslocamentos pendulares cotidianos da população. Geograficamente, há o diferencial de quase a totalidade do município de maior importância situar-se na Ilha de Santa Catarina, com apenas uma ligação rodoviária de duas pontes conectando a parte continental à insular. Há também a presença de vastas áreas de preservação permanente (APP), principalmente na porção insular, como morros, lagoas, rios, mangues e dunas, condicionando e restringindo a ocupação urbana na ilha, como se observa na Figura 1. 
Figura 1 - Localização da área de estudo
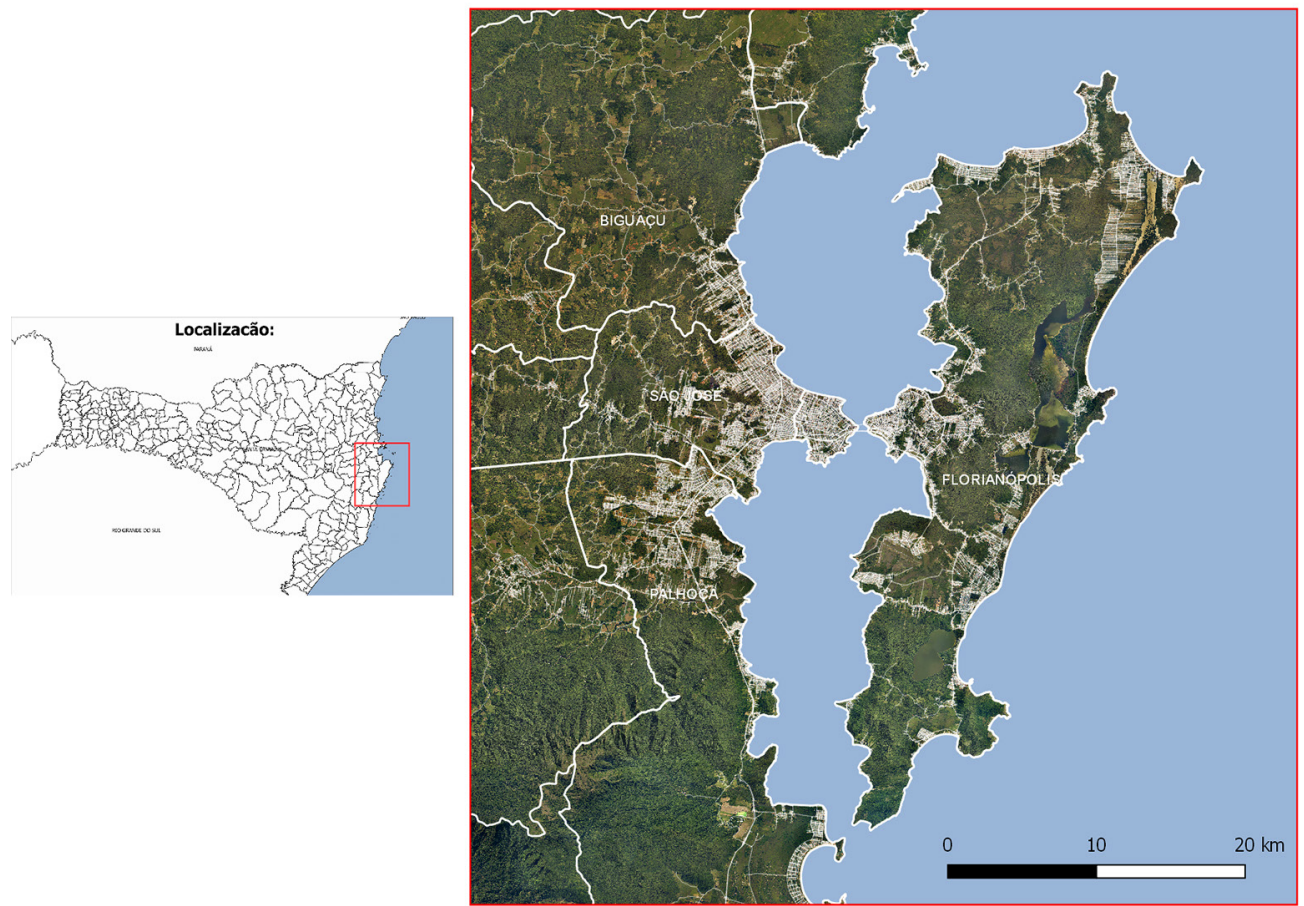

Fonte: Adaptado de levantamento aerofotogramétrico SIGSC.

Os quatro municípios conurbados, em 2010, constituíam-se de 826.584 habitantes, com 351.475 domicílios (IBGE, 2010). A população continental representa cerca de $60 \%$ do total, considerando que os bairros continentais de Florianópolis possuem cerca de 85 mil habitantes e a ilha 336 mil. Observa-se, na Figura 1, que a maior parte da população se concentra próxima às duas baías (Norte e Sul).

Quadro 1 - População urbana, e número de domicílios dos municípios conurbados da Grande Florianópolis

\begin{tabular}{l|c|c}
\hline \multicolumn{1}{c|}{ Município } & População residente & Número de domicílios \\
\hline Biguaçu & 58.206 & 21.226 \\
Florianópolis & 421.240 & 194.819 \\
Palhoça & 137.334 & 58.788 \\
São José & 209.804 & 78.642 \\
\hline
\end{tabular}

Fonte: Tabulação própria a partir do Censo IBGE 2010). 
0 início da ocupação da região teve início no século $\mathrm{XVI}$, mas apenas a partir do século XVIII, com a chegada de imigrantes açorianos em Desterro, ${ }^{3}$ foram fundados os diversos núcleos de povoamento ao redor da Ilha de Santa Catarina e na área continental, cujas localizações e distâncias foram determinadas por sua condição estratégica e também pelo meio de transporte dominante na época, o transporte marítimo. As conexões entre esses núcleos de colonização e destes com Desterro ocorriam mais pelos meios de transporte marítimo do que por terra, o que, inclusive, repercutiu na estruturação urbana de Florianópolis e nos grandes vazios urbanos atuais. A preponderância do transporte marítimo começa lentamente a mudar com a construção da primeira ligação, a Ponte Hercílio Luz, inaugurada em 1926. Sugai (2015) aponta que, décadas após a inauguração da Ponte Hercílio Luz e, principalmente, com a adoção do ônibus, inicia-se o processo de periferização das camadas populares para a área continental. Sobretudo a partir da segunda metade do século $X X$, as populações migrantes de renda mais baixa instalaram-se nos municípios de Palhoça, São José e Biguaçu - locais em que ocorriam carências de infraestruturas urbanas, de serviços públicos e com constante ausência do Estado. 0 alto preço das terras e a precariedade no transporte público também induziram à ocupação, pelas camadas mais pobres, de áreas ambientalmente frágeis e de difícil acesso de Florianópolis, como é o caso de diversas comunidades que, desde o final do século XIX, foram ocupando as encostas do Maciço do Morro da Cruz, próximo ao Centro da cidade.

Além disso, as camadas sociais de maior renda foram concentrando-se na ilha, na península central, em especial na parte norte da península. Durante o século $X X$, parte do setor hegemônico expandiu suas áreas de lazer e residenciais também para a orla da metade norte da ilha, direcionando, para essas áreas, a maior parte dos investimentos públicos que vêm sendo implementados no município desde a década de 1960. Esse processo contínuo de concentração de investimentos públicos, de legislações e de ações privilegiadas, determinou a atual segregação socioespacial apresentada por Florianópolis e a sua área conurbada.

A disparidade entre regiões que, historicamente, receberam investimentos estatais e outras que foram relegadas é evidenciada na Figura 2, que mostra os extremos de renda segundo o Censo de 2010. 0 que se observa é que a grande maioria dos assentamentos urbanos de renda mais baixa se localiza na periferia da área conurbada, a oeste da BR-101. Em um estudo sobre as habitações informais na área conurbada, a pesquisa Infosolo, no ano de 2009, identificou 171 áreas de informalidade e pobreza, muitas delas no próprio município de Florianópolis. Isso revelou uma face pouco conhecida sobre a região, uma vez que grande parte das áreas informais se encontra invisível aos olhos da população, não sendo vistas das grandes vias de circulação (Sugai et al., 2005; Sugai, 2009).

Atualmente, há também uma concentração dos serviços, empregos e instituições na área central do município de Florianópolis, mais especificamente em sua porção insular, mas com oferta significativa no setor continental, principalmente a leste da rodovia BR-101, evidente através da Figura 3. Conforme Villaça (2001), a disponibilidade e o acesso aos serviços públicos determinam o preço dos terrenos 
Figura 2 - Distribuição dos extremos de renda

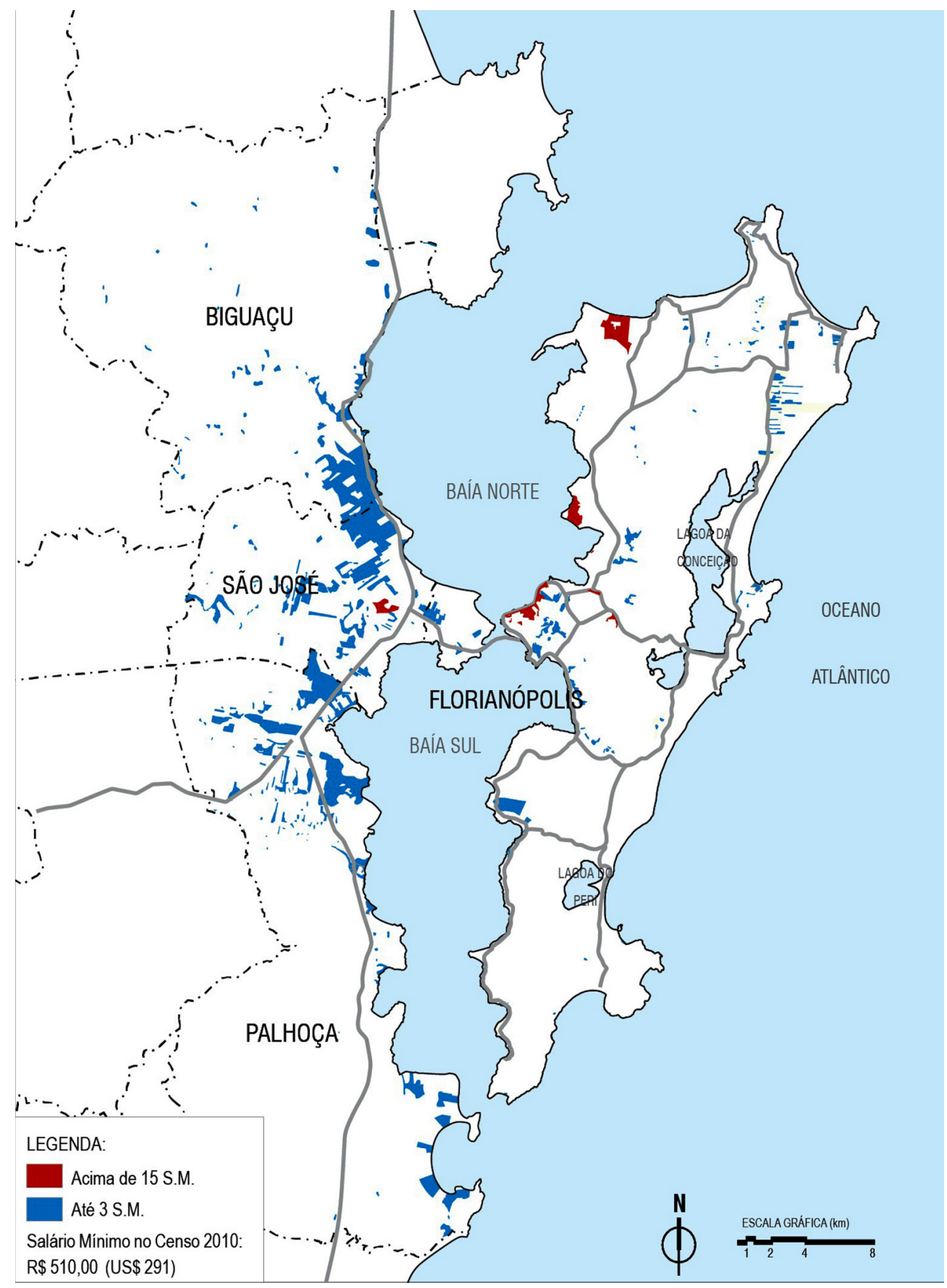

Fonte: Sugai (2015). 
que, por sua vez, influencia a conhecida distribuição espacial não só das camadas sociais, mas também de seu comércio, serviços e indústrias. Através dos preços dos terrenos e, consequentemente, dos imóveis, o resultante é a distribuição das vantagens e desvantagens da cidade, de suas qualidades e de seus defeitos, todos estes socialmente produzidos, mas privadamente apropriados através da localização pela qual se pode pagar.

Figura 3 - Principais serviços e comércios na área conurbada da RMF

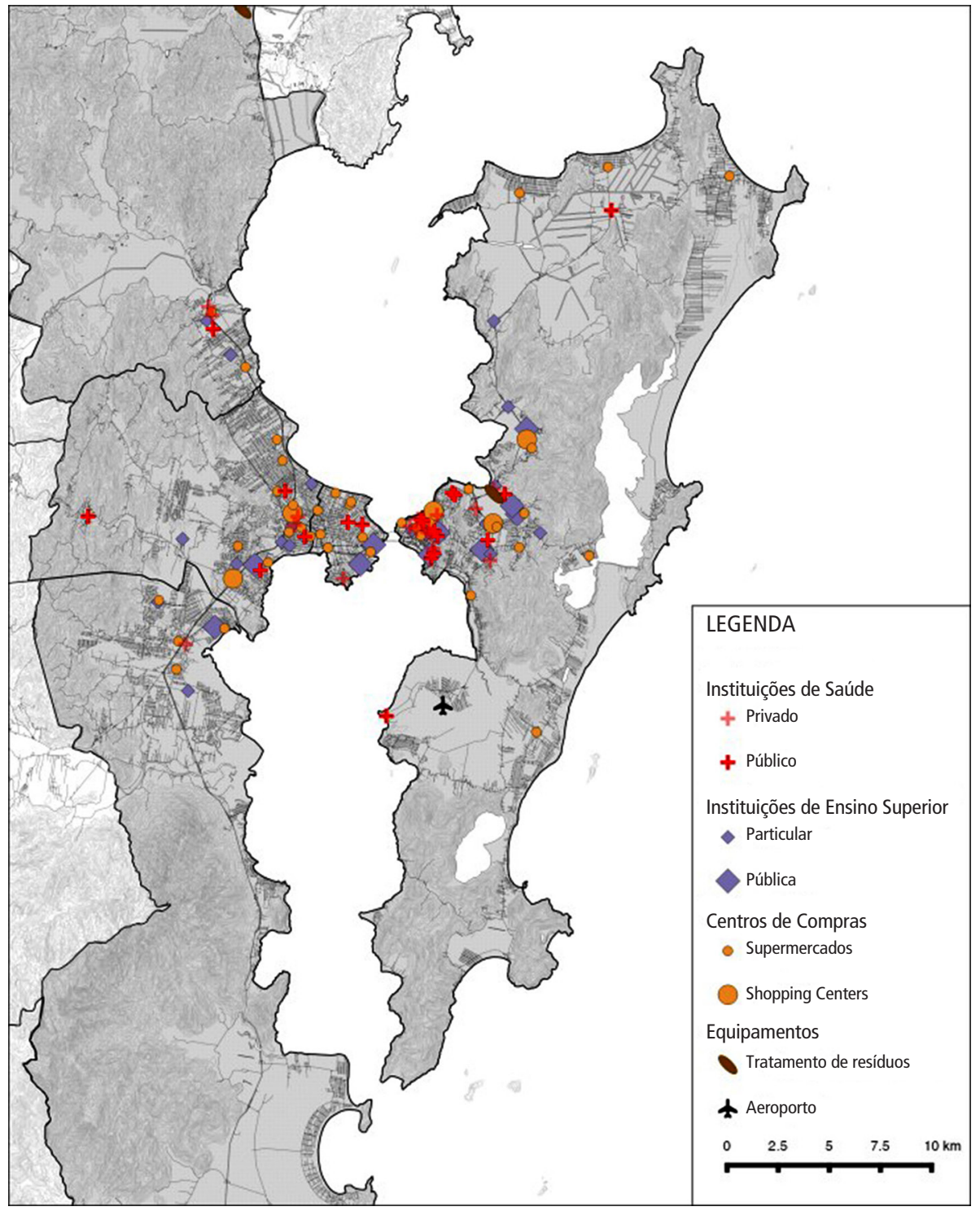

Fonte: Atualização dos dados, a partir de Sugai (2015). 


\section{Os padrões de deslocamentos intermunicipais}

A distribuição demográfica na região metropolitana de Florianópolis, aliada à concentração de serviços e empregos na capital, em especial na área central, e à configuração física do sistema viário, acarreta penosos deslocamentos pendulares intermunicipais diários, principalmente entre ilha e continente. Isso representa o maior desafio à mobilidade da região. Apenas uma conexão na parte mais estreita das baías, com duas pontes de quatro faixas cada, configura a conexão entre as partes continental e insular da região metropolitana, com congestionamentos diários extremamente longos.

A relação de pendularidade diária já citada pode ser comprovada por meio dos dados dispostos na Tabela 1. Nota-se que o município de Florianópolis é o único com mais empregos do que população economicamente ativa, o que significa que demanda um contingente de trabalhadores vindo dos municípios vizinhos preenchendo diariamente seus postos de trabalho. Segundo o Censo 2010
(IBGE, 2010), as atividades dos trabalhadores de Florianópolis vindos de outros municípios são principalmente: os serviços domésticos (28,83\% das vagas de Florianópolis); a construção civil (23,07\% das vagas) e os serviços industriais de utilidade pública (Siup) e de administração pública (23,06\% das vagas). Isso mostra que a mão de obra atraída para o município de Florianópolis é, principalmente, para trabalhos que exigem menores qualificações, com vencimentos mais baixos.

$\mathrm{Na}$ Figura 4, isso fica ainda mais visível. Através dos dados da pesquisa origem-destino do Plano de Mobilidade Urbana Sustentável da Grande Florianópolis (Plamus), observa-se que Florianópolis é o único que atrai mais viagens ${ }^{4}$ do que produz. Dentre os outros municípios, Palhoça apresenta-se como o mais "equilibrado" nesse sentido, e São José é o município que mais pode ser identificado como "dormitório", uma vez que produz muito mais viagens do que atrai, e esse excedente se destina, principalmente, a Florianópolis. Reiterando que há apenas um ponto de ligação rodoviária, pode-se mensurar a gravidade da situação.

Tabela 1 - População economicamente ativa e empregos nos municípios em 2010

\begin{tabular}{|c|c|c|c|c|c|}
\hline \multirow{2}{*}{ Município } & \multicolumn{2}{|c|}{ Moradores do município } & \multirow{2}{*}{$\begin{array}{c}\text { \% População } \\
\text { Economicamente } \\
\text { Ativa }\end{array}$} & \multirow{2}{*}{$\begin{array}{c}\text { Empregos no } \\
\text { município }\end{array}$} & \multirow{2}{*}{$\begin{array}{l}\text { Empregos / } \\
\text { Moradores }\end{array}$} \\
\hline & Total & Que trabalham & & & \\
\hline Biguaçu & 58.206 & 28.221 & 48,48 & 20.169 & 71,47 \\
\hline Florianópolis & 421.240 & 221.915 & 52,68 & 266.062 & 119,89 \\
\hline Palhoça & 137.334 & 71.381 & 51,98 & 50.974 & 71,41 \\
\hline São José & 209.804 & 112.656 & 53,70 & 96.693 & 85,83 \\
\hline Área de Estudo & 826.584 & 434.173 & 52,53 & 433.898 & 99,94 \\
\hline
\end{tabular}

Fonte: IBGE (2010). 
Figura 4 - Total de viagens produzidas e atraídas por município

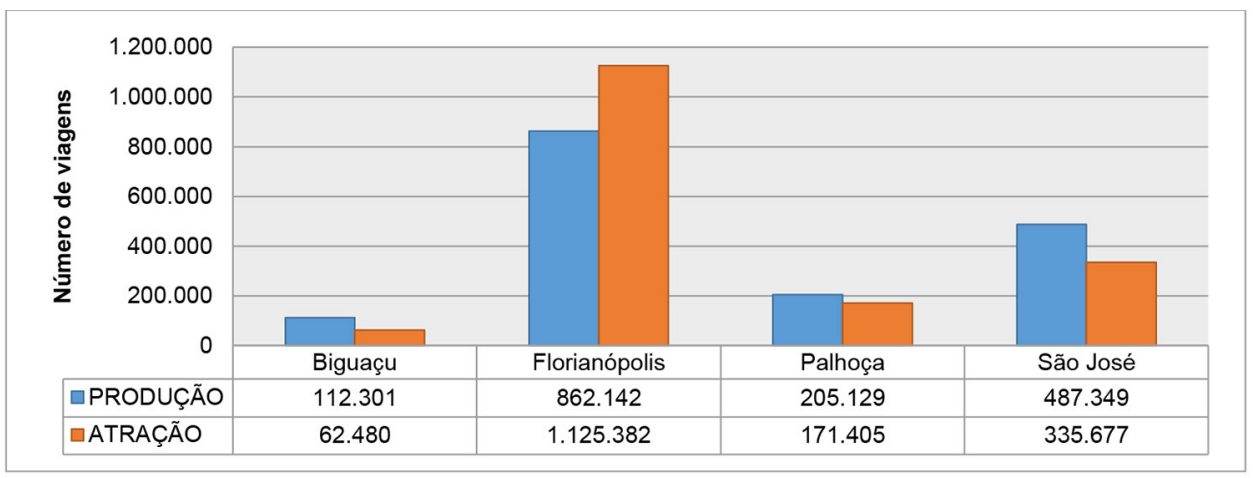

Fonte: Logit Engenharia, Strategy e Machado Meyer (2014).

A situação torna-se mais séria quando se observa a forma como são realizados esses deslocamentos. 0 Plamus diagnosticou que a Região Metropolitana de Florianópolis apresenta uma preponderância das viagens realizadas por transporte individual motorizado (automóveis e motocicletas). Elas representam quase a metade do total (48\%), sendo a maior porcentagem entre as capitais brasileiras. A divisão modal pode ser vista na Figura 5, em que se vê também uma taxa considerada baixa no uso do transporte público se comparado a outras capitais brasileiras, da ordem de $30 \%$ das viagens. Os motivos são diversos e vão desde o estigma ao ônibus, à baixa eficiência das linhas até à alta tarifa cobrada, sobretudo nos deslocamentos que envolvem mais de um município, os quais não possuem integração tarifária.

Figura 5 - Divisão modal da área de estudo do Plamus

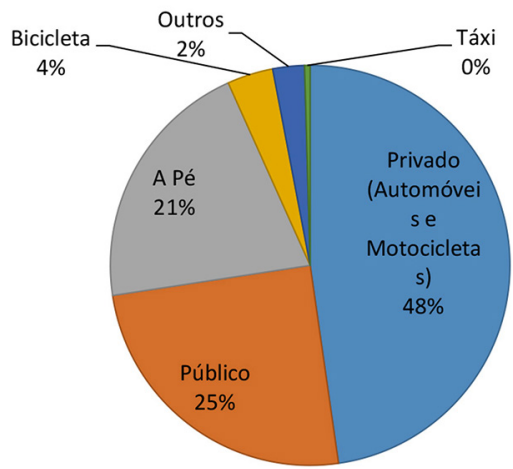

Fonte: Logit Engenharia, Strategy e Machado Meyer (2014). 
0 transporte não motorizado (bicicletas e pedestres), por sua vez, aparece com participação reduzida na divisão modal, possivelmente em decorrência das condições precárias das calçadas, da insegurança em se utilizar a bicicleta como meio de transporte, da insuficiente e descontínua rede de ciclovias e, principalmente, pelo fato de que a grande maioria da população residir afastada dos locais de emprego ou de educação, dificultando esse modo de deslocamento.

Ainda amparados pelos dados da pesquisa origem-destino, Quadro 2 apresenta o tempo médio de viagens, em que o transporte público apresenta uma média de 78 minutos, considerada extremamente alta, e mais que o dobro do tempo médio de viagem dos transportes privados, de 35 minutos. A Figura 6 mostra o histograma dos tempos de viagem, evidenciando que enquanto a maioria das viagens realizadas por transporte individual concentram-se em um período mais curto entre 15 e 30 minutos, com um pico na casa dos 20 minutos, no transporte público observa-se que há uma frequência de viagens praticamente similar entre viagens entre 45 e 105 minutos. Um agravante é que o transporte coletivo é exclusivamente realizado através de ônibus, que disputam espaço com os automóveis nas vias, não contando com nenhum tipo de infraestrutura exclusiva.
Outra questão importante é os ônibus servirem, primordialmente, aos horários de pico, havendo uma redução drástica dos horários fora do pico e durante os finais de semana. Comparando-se a oferta de serviços no pico da tarde do sábado com o pico da tarde no dia útil, verifica-se uma eliminação de $65 \%$ das viagens ofertadas, percentual que atinge $73 \%$ no domingo. Isso acaba por cercear, o acesso à cidade, pelos moradores de áreas mais afastadas e periféricas e sem condições de ter um veículo automotor, sobretudo no que diz respeito a equipamentos culturais e de lazer.

Essa dinâmica se reflete na elevada posse de veículos automotores. Através da Figura 7 se vê o aumento da frota nos quatro municípios da área conurbada de Florianópolis. Entre os anos de 2002 e 2015, houve crescimento de $111,57 \%$ na frota de automóveis e 213,49 na de motocicletas, ao mesmo tempo que a população dos municípios, no mesmo período, cresceu $27,89 \% .^{5} 0$ aumento do poder de compra dos brasileiros, juntamente à facilidade da obtenção de crédito e às políticas de subsídios para a compra de automóveis, aliado ao serviço precário e caro do transporte coletivo e à crescente dispersão das cidades, contribuíram para o aumento da frota na última década.

\section{Quadro 2 - Tempos de deslocamento}

\begin{tabular}{|c|c|}
\hline & Tempo \\
\hline Transporte público & 78 minutos \\
Transporte individual & 35 minutos \\
\hline
\end{tabular}

Fonte: Plamus (Logit Engenharia, Strategy e Machado Meyer, 2014). 
Figura 6 - Histograma dos tempos de deslocamento

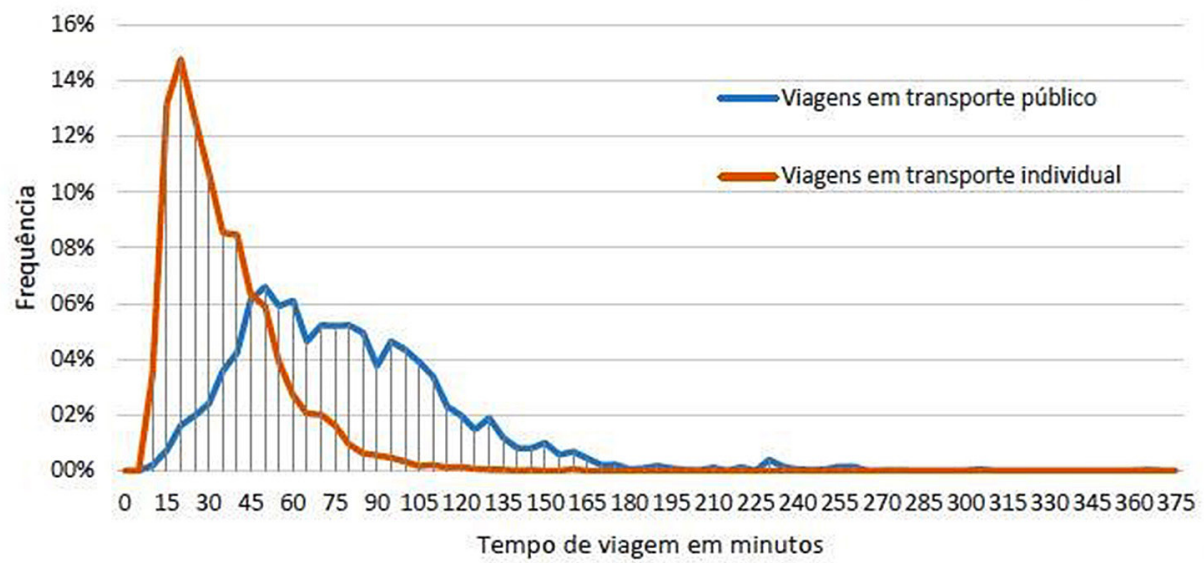

Fonte: Plamus (Logit Engenharia, Strategy e Machado Meyer, 2014).

Figura 7 - Comparação entre o crescimento da frota de automóveis e motocicletas nos municípios da área conurbada de Florianópolis

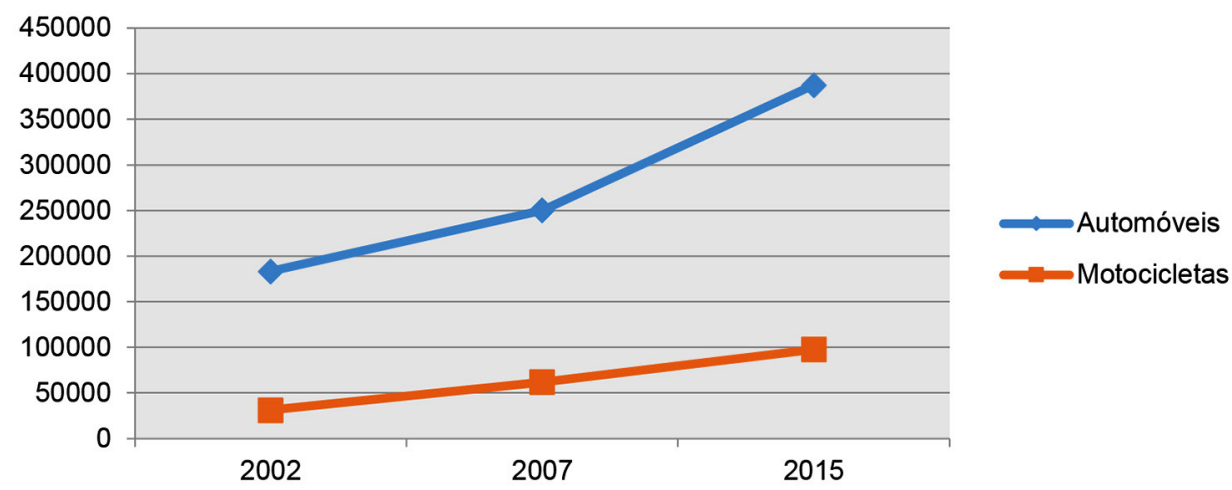

Fonte: Detran-SC (2016). 
Nas Figuras 8 e 9, observa-se a distribuição da frota de automóveis e motocicletas por domicílios, respectivamente. Os dados indicam que, enquanto o maior índice de posse de automóveis coincide com as regiões mais bem localizadas e nas quais se concentra a população de maiores rendimentos, os maiores índices de posse de motocicletas situam-se nas áreas afastadas dos centros urbanos, que também contam com piores atendimentos das linhas de ônibus.

Figura 8 - Taxa de posse de automóveis por domicílios

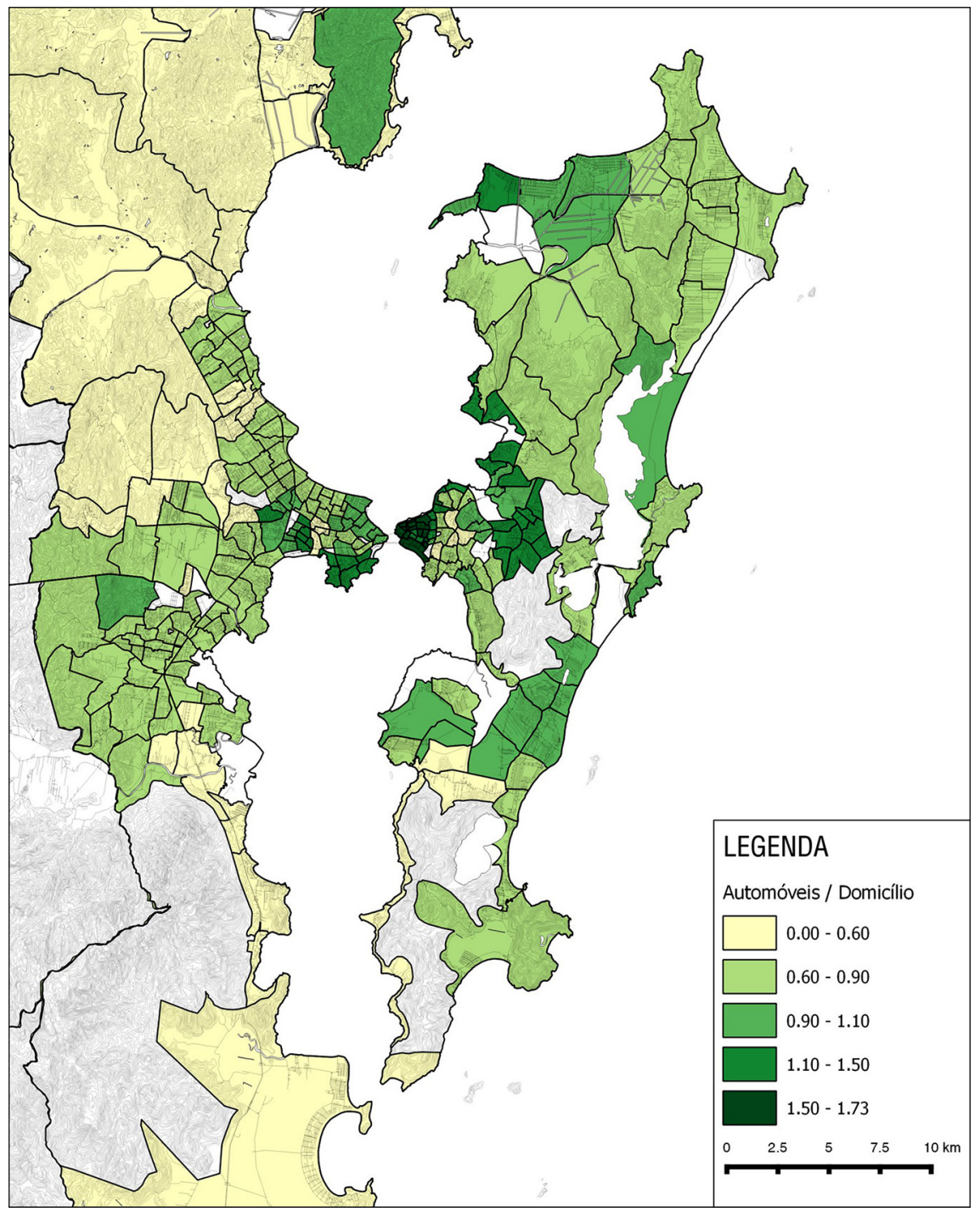

Fonte: Plamus (Logit Engenharia, Strategy e Machado Meyer, 2014). 
Figura 9 - Taxa de posse de motocicletas por domicílios

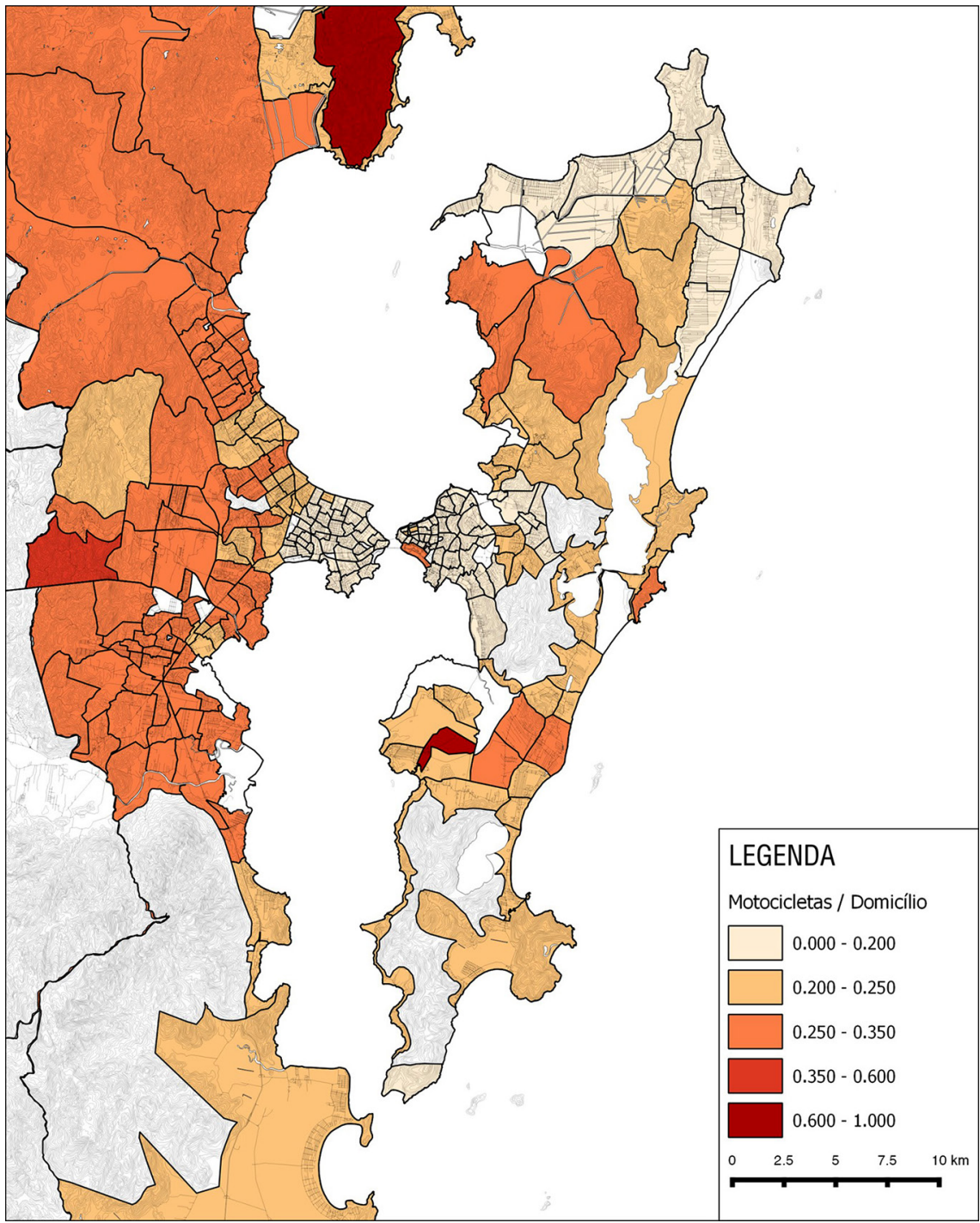

Fonte: Plamus (Logit Engenharia, Strategy e Machado Meyer, 2014).

Em suma, observa-se que a área de estudo apresenta peculiaridades na sua conformação urbana que, aliada a uma divisão modal focada no transporte automotor individual, acaba por incentivar a aquisição de veículos individuais para suprir às necessidades cotidianas. É nesse sentido que o debate acerca da inserção urbana dos empreendimentos do PMCMV ganha relevância. 


\section{0 caso do PMCMV na área conurbada de Florianópolis}

0 Programa Minha Casa Minha Vida foi anunciado no ano de 2009, com o objetivo de atender à demanda habitacional de baixa renda, fazendo com que o mercado incorporasse setores que nunca tiveram oportunidade de adquirir imóveis pelo mercado formal. Em meio à crise, foi das principais estratégias do governo federal para impulsionar a economia brasileira, através de todos os serviços e atividades que a construção civil movimenta, e enfrentar os efeitos da crise econômica global. Os principais atores do PMCMV são a Caixa Econômica Federal, as prefeituras e o setor da construção civil. 0 montante de recursos alocados para o programa, para atender às famílias com renda entre 0 a 10 salários mínimos, constituiu-se de fato inédito na história do País, que vinha de um período de 20 anos com exíguos investimentos federais no setor habitacional, após o fim do Banco Nacional de Habitação (BNH). Os subsídios oferecidos são divididos entre 3 faixas de renda, segundo a renda familiar. A faixa 1 inclui as famílias de renda mais baixa, com total de até 3 salários mínimos. A faixa 2 inclui renda familiar entre 3 e 6, enquanto a faixa 3, renda entre 6 e 10 salários mínimos. Cabe salientar que é justamente na faixa de renda 1 que se localiza a maior parte do déficit habitacional.
De acordo com a Caixa Econômica Federal, até o mês de junho de 2016, 12.379 unidades habitacionais foram contratadas nos quatro municípios da área conurbada de Florianópolis. Dessas unidades, 49,5\% localizavam-se no município de Palhoça, 26,3\% em São José e 16,4 \% em Biguaçu. Florianópolis, por conta da segregação socioespacial e do alto preço dos terrenos, abordado no item anterior, contava com 7,75\% dos empreendimentos, dois deles situados na área continental e quatro na ilha de Santa Catarina, sendo, na ilha, apenas empreendimentos das faixas de renda 2 e 3 . A grande maioria dos empreendimentos do PMCMV localiza-se na periferia da área conurbada, principalmente nos municípios de Palhoça, São José e Biguaçu (Figuras 10 e 11).

Constata-se, ainda, que há uma preponderância nos empreendimentos da faixa de renda 2 e 3 (Ver Quadro 3), que respondem por $89 \%$ do total na área conurbada, confirmando a tendência em todo o território brasileiro, uma vez que possibilita maior lucratividade por parte dos empreendedores. É importante salientar o percentual extremamente baixo de empreendimentos para a faixa de renda 1, mais subsidiada, que representa apenas $12 \%$ das unidades habitacionais contratadas no período e que evidencia a dificuldade de enfrentamento real ao déficit habitacional na área conurbada de Florianópolis. 


\section{Quadro 3 - Totais de unidades habitacionais contratadas pelo PMCMV até junho de 2016}

\begin{tabular}{|c|c|c|c|c|c|}
\hline Município & Faixa de Renda & \multicolumn{2}{|c|}{$\begin{array}{l}\text { Unidades Habitacionais (UH) } \\
\text { Contratadas }\end{array}$} & Totais (UH) & $\begin{array}{c}\text { Porcentagens } \\
(\%)\end{array}$ \\
\hline \multirow{2}{*}{ Biguaçu } & Faixa 1 & 512 & $25,17 \%$ & \multirow{2}{*}{2.034} & \multirow{2}{*}{$16,43 \%$} \\
\hline & Faixas 2 e 3 & 1.522 & $74,83 \%$ & & \\
\hline \multirow{2}{*}{ Florianópolis } & Faixa 1 & 166 & $17,31 \%$ & \multirow{2}{*}{959} & \multirow{2}{*}{$7,75 \%$} \\
\hline & Faixas 2 e 3 & 793 & $82,69 \%$ & & \\
\hline \multirow{2}{*}{ São José } & Faixa 1 & 0 & $0,00 \%$ & \multirow{2}{*}{3.256} & \multirow{2}{*}{$26,30 \%$} \\
\hline & Faixas 2 e 3 & 3.256 & $100,00 \%$ & & \\
\hline \multirow{2}{*}{ Palhoça } & Faixa 1 & 800 & $13,05 \%$ & \multirow{2}{*}{6.130} & \multirow{2}{*}{$49,52 \%$} \\
\hline & Faixas 2 e 3 & 5.330 & $86,95 \%$ & & \\
\hline Totais & & & & 12.379 & \\
\hline
\end{tabular}

Fonte: Dados obtidos junto à Caixa Econômica Federal, na Gerência de Filial de Desenvolvimento Urbano e Rural, em junho de 2016.

Figura 10 - Fotografia aérea no município de Palhoça, ano de 2016

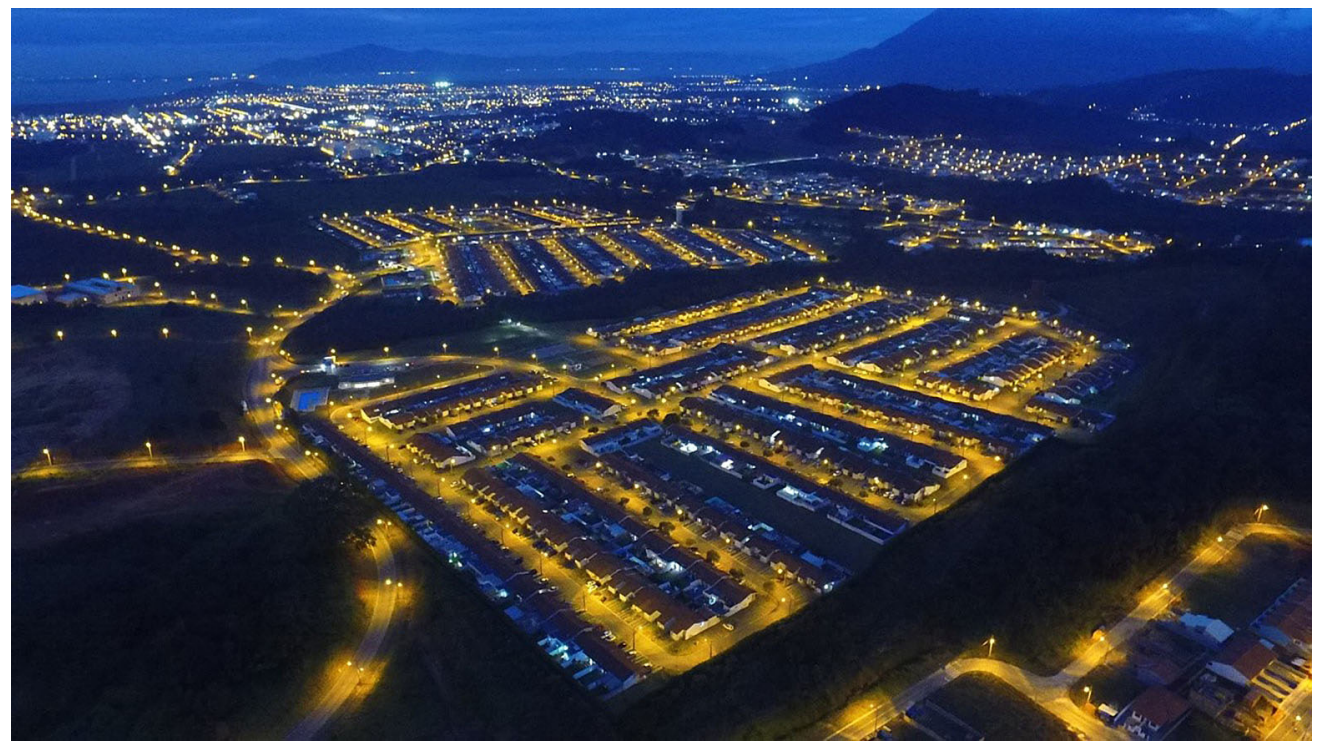

Fotografia: Felipe Cemin Finger. 
Figura 11 - Mapa dos empreendimentos Minha Casa Minha Vida

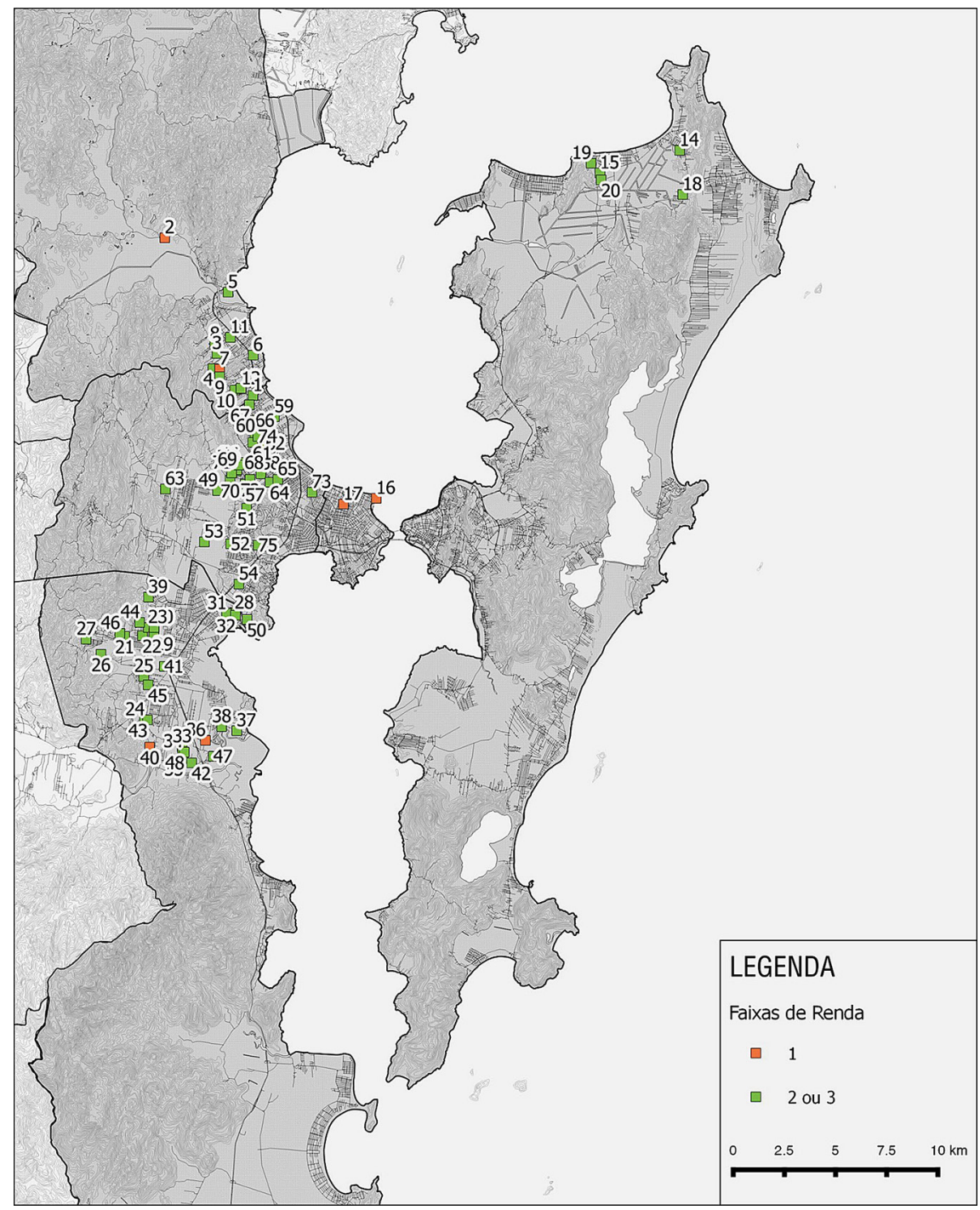

Fonte: Caixa Econômica Federal (2016).

Os empreendimentos do PMCMV, portanto, têm sido construídos nas áreas mais periféricas, sobretudo nos municípios de Palhoça e São José, amplificando o processo de periferização e tornando-se agente imprescindível dessa dispersão urbana, uma vez que contam com o aval e o apoio do poder público, sobretudo através da dotação de infraestruturas. Não obstante, a dispersão urbana coexiste com uma quantidade elevada de vazios urbanizados, glebas com infraestrutura adequada e consolidada, mas que são subutilizadas ou mantidas pelo capital imobiliário para fins especulativos. Isto dificulta o acesso dos moradores a comércio e serviços 
Figura12 - Escala dos empreendimentos Minha Casa Minha Vida

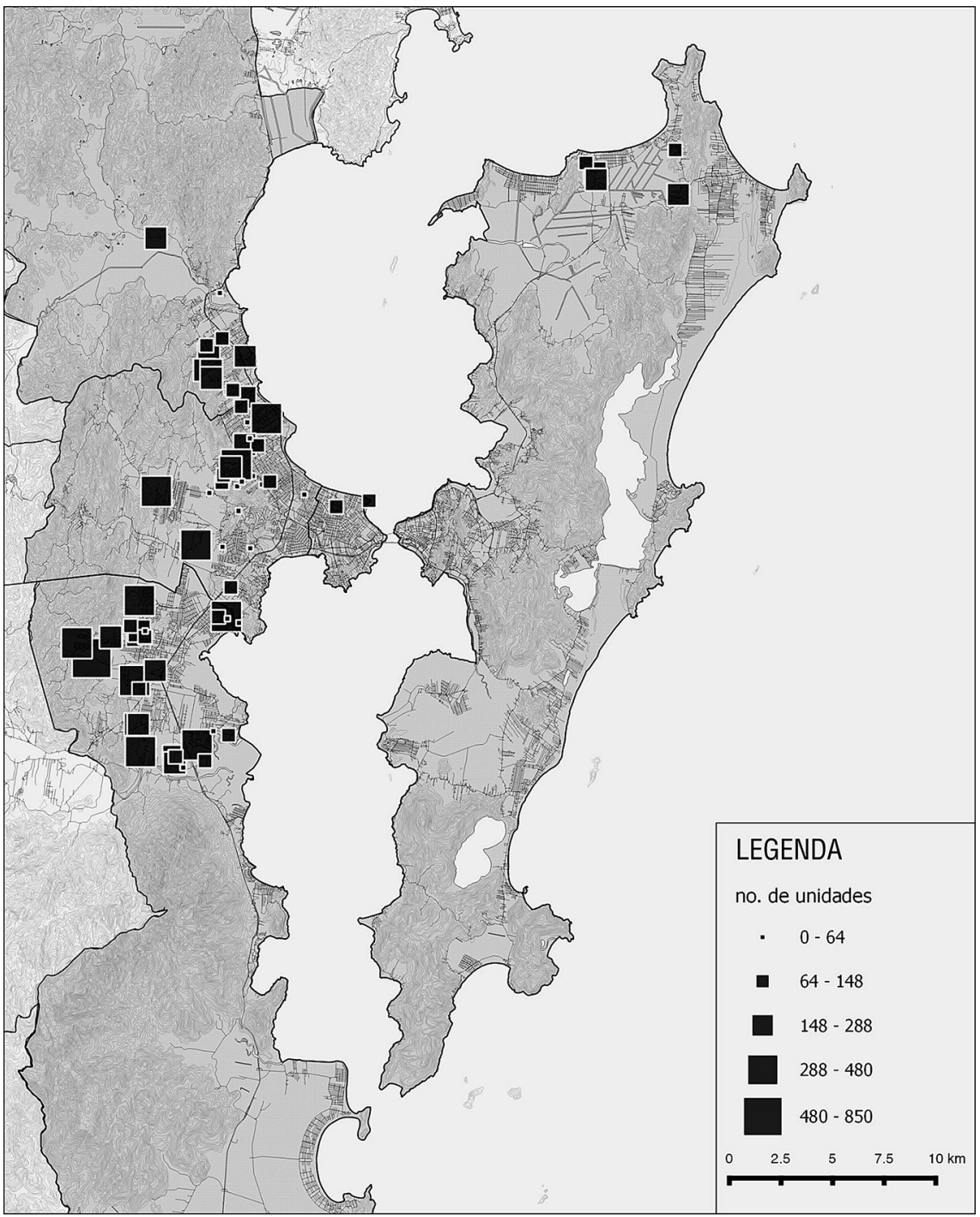

Fonte: Caixa Econômica Federal (2016).

cotidianos. Essa condição se aplica também aos serviços básicos de saúde, educação, lazer. A população residente é obrigada a deslocar-se para outras localidades, impactando nos sistemas de transporte e diminuindo a qualidade de vida. Vê-se também, através da Figura 10, que os empreendimentos com mais unidades habitacionais são, justamente, os mais afastados, conformando vizinhanças inteiras de conjuntos habitacionais murados, com pouquíssimos serviços e comércios de apoio.

Ilustrando a carência de pequenos comércios lindeiros, verificou-se, próximo à entrada de um dos empreendimentos no município 
de Palhoça, em um sábado pela manhã, um caminhão de feira vendendo diversas frutas e hortaliças (Figura 13), além de um automóvel em que eram vendidos produtos de limpeza, conformando um mercado informal que é uma opção improvisada para mitigar o isolamento do condomínio.

Esse processo de indução ao espraiamento urbano provoca uma série de consequências socioambientais, urbanas e, principalmente, para a reprodução da força de trabalho. Entre elas, destacam-se a deterioração dos recursos naturais e da qualidade ambiental, a descontinuidade das redes de infraestrutura, os altos custos de urbanização em extensas distâncias e a conformação de espaços segregados espacialmente, o que contribui, entre outras consequências, para o agravamento dos problemas sociais.

A urbanização dispersa também determina graves restrições para o deslocamento dos trabalhadores em função da redução da eficiência e do aumento dos custos e das tarifas do sistema de transporte público. Os deslocamentos pendulares configuram-se como extremamente inconvenientes para as empresas de transporte coletivo, uma vez que os ônibus saem dos bairros lotados no período da manhã

Figura13 - Comércio informal no entorno do empreendimento Moradas da Palhoça, em abril de 2016

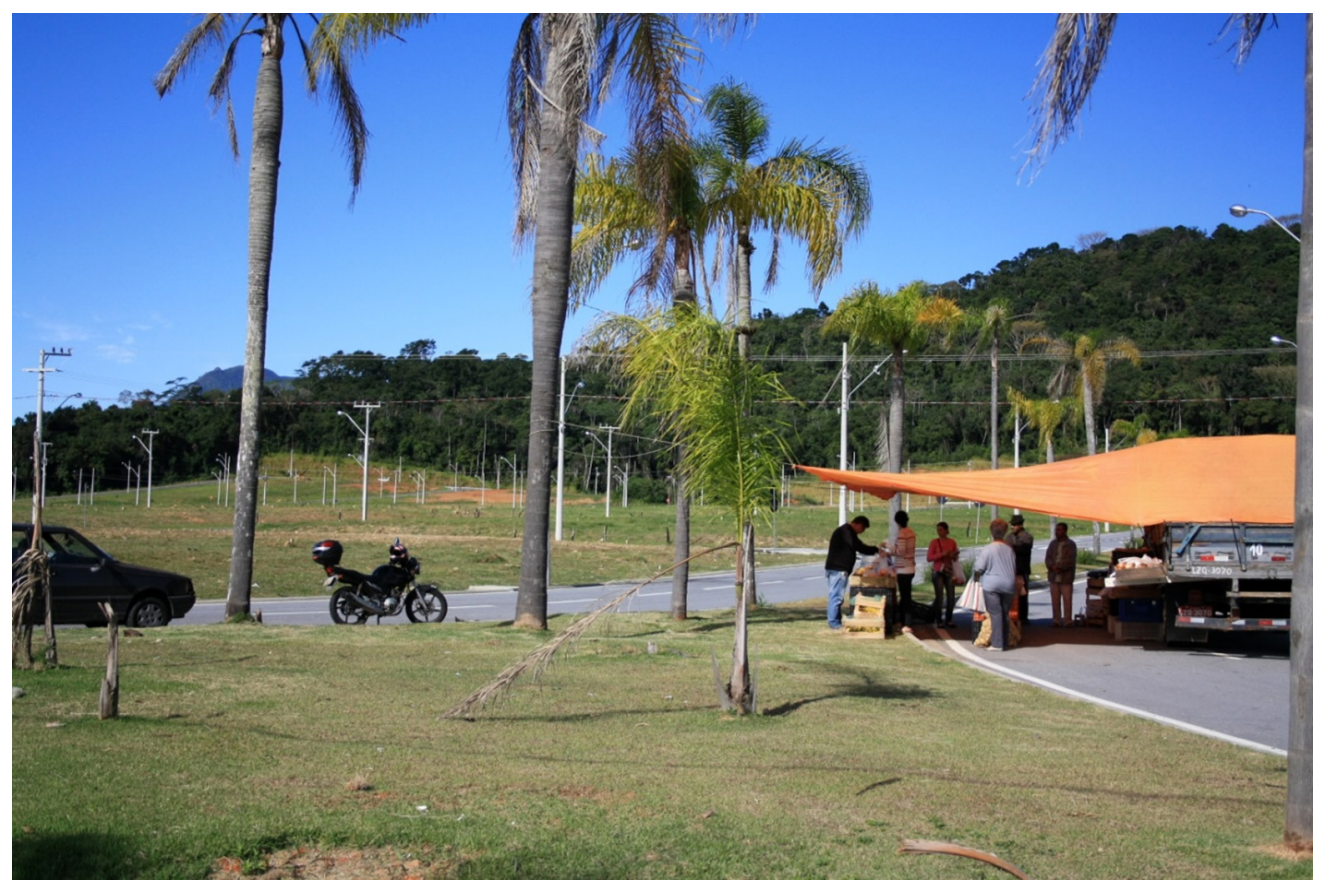

Fonte: Acervo próprio. 
e retornam ao bairro completamente vazios e, por não apresentarem a rentabilidade esperada pelos operadores de transporte, estes comumente diminuem o número de veículos em operação ao mínimo e tentam repassar os custos à tarifa. Essa redução da receita das empresas, devido aos grandes percursos dos ônibus sem demanda constante de passageiros, acaba sendo repassada pelo poder público ao conjunto da sociedade e, principalmente, aos usuários do transporte coletivo através do aumento da tarifa, o que, além de onerar todo o sistema, também encarece e restringe os deslocamentos intraurbanos dos trabalhadores. No caso da área conurbada de Florianópolis, é importante salientar a ocorrência de um agravante referente a ofertas de empregos e oportunidades, o que determina um tumultuado deslocamento pendular cotidiano de parte dos moradores dos diversos municípios em direção à capital para trabalhar, ou mesmo para estudar, ou acessar outros diferentes serviços e atividades.

Ferreira (2012) pontua que o espraiamento urbano, a segregação socioespacial, a consolidação de grandes vazios urbanos, os bairros monofuncionais e a formação de áreas isoladas ou desarticuladas da malha urbana, sem diversidade de usos e grupos sociais, caracterizam o padrão de produção das cidades - padrão que já se mostrou insustentável do ponto de vista ambiental, econômico e social. Isso se deve, sobretudo, ao preço dos terrenos, que dificulta a implantação de unidades habitacionais para as camadas de renda mais baixas em áreas bem localizadas e com todos os serviços urbanos adequados. Esses conjuntos habitacionais desconectados do tecido urbano, com escassas opções de serviços, comércios e lazer, além de serem servidos por pouquíssimas linhas de ônibus, tornam a opção do transporte individual motorizado quase uma exigência, quando também não ocorrem a locação ou a negociação clandestina das unidades habitacionais.

0 valor elevado da tarifa e a frequência deficiente de ônibus nas áreas periféricas tornam-se grandes inibidores da utilização do transporte coletivo, como pode ser constatado tomando-se o caso do empreendimento Residencial Saudade, situado no município de Biguaçu (Figura 14). Dentre as cinco linhas de ônibus que operam na via contígua a esse conjunto habitacional - Saudade, Três Riachos, Sorocaba, Três Riachos até Viaduto Janaína e o Sorocaba até Viaduto Janaína -, as três primeiras linhas de ônibus dirigem-se ao centro de Florianópolis e as outras duas linhas dirigem-se ao centro do município de Biguaçu. Os horários de ônibus no sentido bairro-centro nos dias úteis são bastante restritos, concentrando-se no período da manhã e rareando até o final da tarde. Na linha Saudade, a que mais bem atende ao empreendimento, constatou-se que, dos 11 horários de saída, 4 deles ocorrem antes das 7 horas da manhã. Essa restrição de horários acaba por criar sérios cerceamentos para a vida dos moradores, não apenas limitações para os necessários deslocamentos cotidianos, mas também impossibilidade de estudar, de obter atendimentos médico e até mesmo de exercer qualquer atividade profissional fora do horário convencional (em bares, restaurantes, supermercados ou shoppings centers, atividade de vigilância noturna, de serviços de limpeza pública em contraturnos, etc.).

As linhas municipais de transporte coletivo que atendiam ao Residencial Saudade, em 2016 , tinham o custo de $R \$ 3,65$ e de $R \$ 4,30$, 
Figura 14 - Fotografia aérea no município de Biguaçu, em 2016

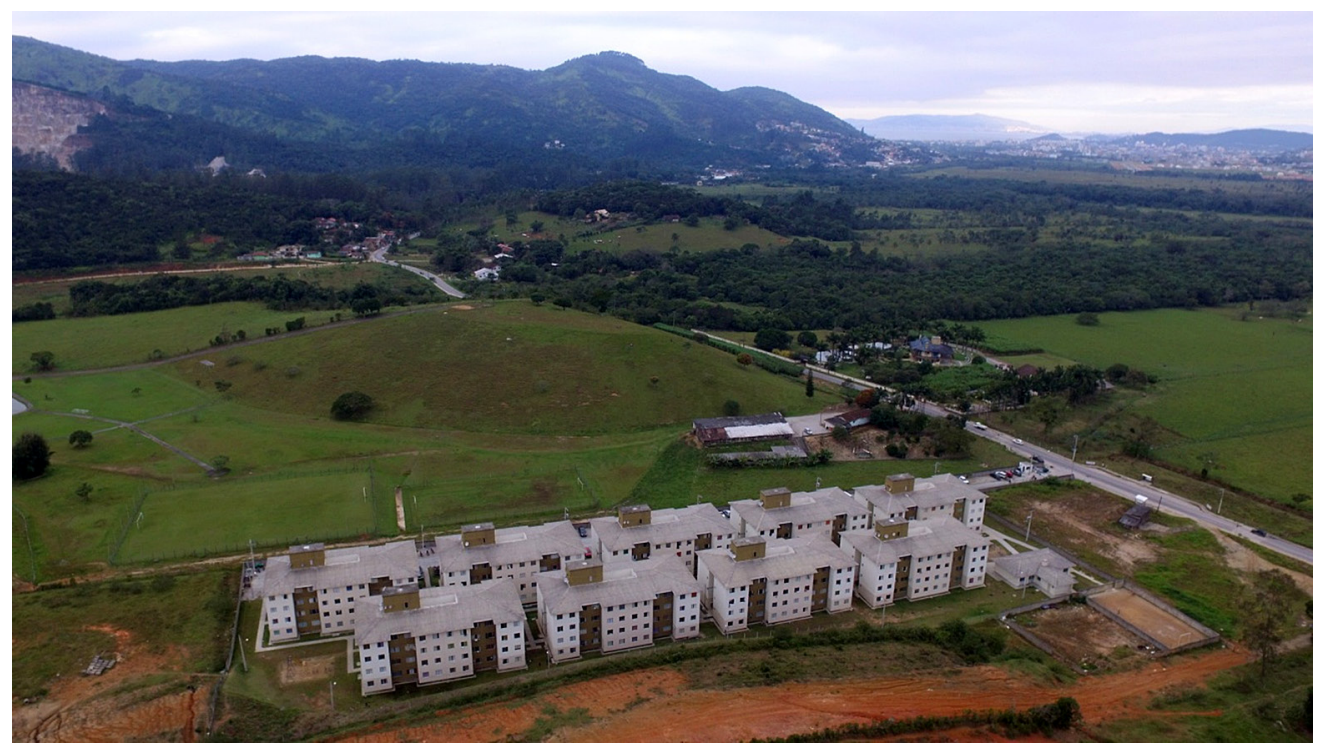

Fotografia: Felipe Cemin Finger.

enquanto as linhas intermunicipais custavam $R \$ 5,10$ e $R \$ 6,50$. Considerando que esse empreendimento atende às famílias de menor rendimento, na época com renda familiar de até $R \$ 1.800,00$, pode-se mensurar o impacto das tarifas nos orçamentos familiares, ponderando que, se o destino não for o centro de Florianópolis, há a necessidade de tomar outro ônibus, pagando outra passagem, visto que não há integração tarifária entre os municípios da região. Ou seja, se o destino final fosse Florianópolis, apenas esse membro da familia deveria gastar com passagens o valor diário entre $R \$ 17,50$ a $R \$ 21,60$, constituindo-se num gasto mensal entre $R \$ 385,00$ a
$R \$ 475,00$, o que representava entre $21,3 \%$ a $26,3 \%$ do rendimento mensal da familia. Isso sem considerar a necessidade de gastos com transporte coletivo de outros membros da família, para trabalhar, estudar ou outra necessidade, o que evidencia graves contradições que prenunciam obstáculos à permanencia desses moradores no conjunto ou à sobrevivência financeira da família. Dessa maneira, o exemplo confirma a importância da localização do conjunto habitacional no contexto urbano, dos estudos sobre os deslocamentos intraurbanos e demais necessidades urbanas, como determinantes para garantir a eficácia das políticas habitacionais e urbanas. 


\section{Considerações finais}

Este artigo procurou mostrar como, diante de uma estrutura socioespacial segregada, como a área conurbada de Florianópolis, fruto de décadas de sucessivos e massivos investimentos públicos distribuídos de forma desigual e com uma problemática e restrita condição de mobilidade urbana, a localização dos empreendimentos habitacionais do PMCMV constituiu-se também em fator de indução e incentivo para a periferização urbana, determinando significativas repercussões urbanas, na dinâmica socioespacial, na mobilidade urbana e na vida dos moradores desses conjuntos habitacionais.

Procurou, por um lado, apontar as características e sérias limitações da mobilidade urbana na área conurbada de Florianópolis, inclusive indicando que a atual divisão modal adotada se torna quase que insustentável e onera ainda mais o sistema de ônibus, já ineficiente e custoso. Por outro lado, procurou mostrar que a localização dos investimentos dos empreendimentos do Programa Minha Casa Minha Vida vem intensificando um processo de espraiamento urbano dos municípios situados na área continental. 0 artigo, também, evidenciou que os investimentos privados com subsídios públicos vêm transformando algumas das franjas urbanas em periferias monofuncionais, com grande número de novas habitações, muitas vezes fora de áreas urbanizadas e com poucos pontos de comércio, escolas e outros tipos de serviços, o que exige intensa e cotidiana movimentação de seus moradores.

Junto a isso, esse forte incremento em zonas urbanas periféricas não vem recebendo investimentos proporcionais no que tange aos sistemas de transportes, especialmente de transportes coletivos, os quais se tornam extremamente onerosos e com baixa eficiência, principalmente em regiões distantes e com menor densidade. Confirmou-se que $94 \%$ dos empreendimentos da área conurbada estão localizados na porção continental da área de estudo, sendo a grande maioria, 92\% (11.420 unidades habitacionais, do total de 12.379), localizada nos municípios de Palhoça, Biguaçu e São José. No período entre 2009 e maio de 2016, dos 76 empreendimentos contratados pelo PMCMV na área conurbada, apenas sete deles foram contratados em Florianópolis, e, destes, nenhum dos cinco que estão na Ilha de Santa Catarina pertencem à faixa de renda 1 .

No município de Palhoça, por exemplo, o PMCMV determinou um incremento de mais de 6 mil domicílios, sobretudo nos bairros periféricos, configurando-se num acréscimo de cerca de $10 \%$ no número total de domicílios, segundo o Censo de 2010 do IBGE. Destes, a grande maioria localiza-se a cerca de $8 \mathrm{~km}$ do centro municipal e a $23 \mathrm{~km}$ do centro de Florianópolis. Essa situação é bastante similar nos municípios de São José e Biguaçu.

Tal dispersão urbana deverá gerar ainda maiores custos públicos e privados para a mobilidade, além de custos de construção e manutenção de infraestruturas, que deverão ser assumidos pelo conjunto da população, enquanto os lucros dos empreendimentos foram absorvidos privadamente. Além disso, esse processo de dispersão e os investimentos habitacionais em áreas já isoladas e segregadas conformarão um processo de intensificação da apartação social e espacial, não apenas aprofundando a segregação socioespacial, mas permitindo a reprodução das históricas desigualdades sociais. 
Há de se apontar que os investimentos do PMCMV também trouxeram benefícios para os novos moradores, pois permitiram dignidade a comunidades que se encontravam em condições habitacionais precárias.

Em suma, este artigo procurou evidenciar que, com a priorização dos interesses do capital imobiliário e a ausência de maior controle no uso e ocupação da terra urbana, o PMCMV acaba por asseverar os problemas urbanos já presentes nas cidades brasileiras. Além disso, a elaboração de políticas públicas dissociadas (no caso, política habitacional e política de mobilidade urbana focada na isenção de impostos) amplifica ainda mais as disparidades, refletindo-as cotidianamente na vida dos cidadãos, culminando em tempos perdidos em viagens e custo. 0 espraiamento urbano e a produção de novos vazios urbanos gerarão maiores custos para a mobilidade, para a manutenção e administração das cidades - custos que deverão ser assumidos pelo conjunto da população, enquanto os lucros dos empreendimentos foram absorvidos privadamente. 0 processo de dispersão e os investimentos habitacionais em áreas já isoladas e segregadas conformarão um processo de intensificação da apartação social e espacial, não apenas aprofundando a segregação socioespacial no contexto da área conurbada, mas permitindo a reprodução das históricas desigualdades sociais.

\section{Eduardo Leite Souza}

Universidade Federal de Santa Catarina, Programa de Pós-Graduação em Urbanismo, História e Arquitetura da Cidade, Observatório da Mobilidade Urbana. ArchDaily Brasil. Florianópolis, SC/Brasil. dudulsouza@gmail.com

\section{Maria Inês Sugai}

Universidade Federal de Santa Catarina, Curso de Graduação em Arquitetura e Urbanismo, Programa de Pós-Graduação em Urbanismo, História e Arquitetura da Cidade, Programa de Pós-Graduação em Arquitetura e Urbanismo. Florianópolis, SC/Brasil.

misugai2@gmail.com 


\section{Notas}

(1) O Minha Casa Minha Vida é um programa do governo federal lançado em 2009, para atender o mercado de habitação das camadas sociais de mais baixa renda.

(2) A região da Grande Florianópolis abrange 22 municípios. O denominado "Núcleo metropolitano e área de expansão" abrange 9 municípios: Florianópolis, São José, Palhoça, Biguaçu, Santo Amaro da Imperatriz, Governador Celso Ramos, Antônio Carlos, Águas Mornas e São Pedro de Alcântara. Já a área de estudo do Plamus, além dos 9 municípios do núcleo, abrangeu Angelina, Anitápolis, Rancho Queimado e São Bonifácio.

(3) Nossa Senhora de Desterro e Desterro foram antigas denominações de Florianópolis, que teve a atual designação no final do século XIX.

(4) Entende-se que o lugar onde a pessoa reside é o ponto produtor de viagens, sempre e quando algum dos extremos da viagem for o domicílio. O outro extremo da viagem assume-se como o ponto atrator de viagens. Para as viagens nas quais nenhum dos extremos da viagem é o domicílio, a origem é considerada como ponto de produção, enquanto o destino, ponto de atração.

(5) Considerou-se a população do Censo 2000 e a estimativa populacional para o ano de 2015.

\section{Referências}

AMORE, C. S. (2015). "Minha Casa Minha Vida para iniciantes". In: AMORE, C. S., SHIMBO, L. Z. e RUFINO, M. B. C. (orgs.). Minha casa... e a cidade? Avaliação do programa minha casa minha vida em seis estados brasileiros. Rio de Janeiro, Letra Capital.

AMORE, C. S., SHIMBO, L. Z. e RUFINO, M. B. C. (orgs.). (2015). Minha casa... e a cidade? Avaliação do programa minha casa minha vida em seis estados brasileiros. Rio de Janeiro, Letra Capital.

CARDOSO, A. L., ARAGÃO, T. A. e ARAUJO, F. de S. (2011). Habitação de Interesse Social: Política ou mercado? Reflexos sobre a construção do espaço metropolitano. In: XIV ENCONTRO NACIONAL DA ANPUR, 14. Anais.. Rio de Janeiro, Anpur, pp. 1-20.

CARDOSO, A. L. (org.) (2013). O programa Minha Casa Minha Vida e seus efeitos territoriais. Rio de Janeiro, Letra Capital.

DETRAN-SC - Departamento Estadual de Trânsito de Santa Catarina (2016). Frota de veículos por município (mensal). Disponível em: http://www.detran.sc.gov.br/index.php/estatistica/veiculos. Acesso em: 28 mar 2016.

FERREIRA, J. S. W. (coord.). (2012). Produzir casas ou construir cidades? Desafios para um novo Brasil urbano. São Paulo, Fupam.

IBGE - INSTITUTO BRASILEIRO DE GEOGRAFIA E ESTATÍSTICA. Censo demográfico 2010: Resultados gerais da amostra. Rio de Janeiro, IBGE. 
LOGIT ENGENHARIA, STRATEGY e MACHADO MEYER (2014). Plano de Mobilidade Urbana Sustentável da Grande Florianópolis (Plamus). Florianópolis.

PEQUENO, R. e ROSA, S. V. (2015). “Inserção urbana e segregação espacial: análise do Programa Minha Casa Minha Vida em Fortaleza”. In: AMORE, C. S., SHIMBO, L. Z. e RUFINO, M. B. C. (org.) (2015). Minha casa... e a cidade? Avaliação do programa minha casa minha vida em seis estados brasileiros. Rio de Janeiro, Letra Capital.

PEREIRA, E. M. (coord.) (2015). Indicadores de urbanidade como aprimoramento do Programa Minha Casa Minha Vida. Relatório técnico-científico MCidades/CNPq/MCTI no 11/2012. Florianópolis, Laboratório Cidade e Sociedade.

SOUZA, E. L. (2016). A periferização dos empreendimentos do programa Minha Casa Minha Vida e suas consequências na dinâmica socioespacial e na mobilidade urbana da Área Conurbada de Florianópolis. Dissertação de Mestrado. Florianópolis, Universidade Federal de Santa Catarina.

SUGAI, M. I. (2003). Os investimentos públicos e a dinâmica sócio-espacial na produção da segregação urbana . In: X ENCONTRO NACIONAL DA ANPUR, 10. Anais...Belo Horizonte, Anpur, pp. 1-19.

(2009). "Há favelas na 'Ilha da Magia'”? In: ABRAMO, P. (org.). Favela e mercado informal: a nova porta de entrada dos pobres nas cidades brasileiras. Porto Alegre, Antac.

(2015). Segregação silenciosa: investimentos públicos e dinâmica socioespacial na área conurbada de Florianópolis (1970-2000). Florianópolis, Editora da UFSC.

SUGAI, M. I., PERES, L. F. B., RECHE, D. e LONARDONI, F. M. (2005). Mercados informais de solo nas cidades brasileiras e acesso dos pobres ao solo urbano: área conurbada de Florianópolis. Florianópolis, Rede Infosolo/Ippur/UFRJ.

VILLAÇA, F. (1986). O que todo cidadão precisa saber sobre habitação. São Paulo, Global. (2001). Espaço Intra-urbano no Brasil. São Paulo, Studio Nobel.

Texto recebido em 15/set/2017 Texto aprovado em 21/nov/2017 